\title{
АНАЛІЗ СУДОВОЇ ПРАКТИКИ ЩОДО БУЛІНГУ В ОСВІТНІХ ЗАКЛАДАХ УКРАЇНИ
}

Постановка проблеми. Натепер проблема булінгу є актуальною у всьому світі. Важко знайти людей, які б хоч раз у житті не ставали учасниками булінгу. Про це свідчать статистичні дані. Так, дослідженням ЮНІСЕФ за 2017 рік встановлено: 67\% дітей в Україні віком від 11 до 17 років стикалися з проблемою булінгу; $24 \%$ дітей стали жертвами булінгу; $48 \%$ дітей нікому не розповідали про випадки булінгу; 44\% школярів були спостерігачами булінгу, але ігнорували його, бо їм було страшно за себе; більшість дітей булять за те, що вони виглядають, говорять, думають не так, як інші діти. Кожна друга дитина віком від 13 до 15 років - приблизно 150 мільйонів дітей у світі - повідомляють, що зазнавали насильства з боку однолітків у школах або поблизу школи. За даними Всесвітньої організації охорони здоров'я (ВОО3), Україна посідає четверте місце серед країн Європи за рівнем прояву булінгу серед дітей. Укрінформ повідомляє, що станом на 16.02.2021 p. близько 70\% дітей в Україні стикаються з булінгом [7].

19.01.2019 р. набув чинності Закон України «Про внесення змін до деяких законодавчих актів України щодо протидії булінгу (цькуванню)», яким було закріплено адміністративну відповідальність за здійснення булінгу, а також визначено поняття «булінг», його ознаки та права й обов'язки відповідальних осіб у разі прояву дій, які можна ідентифікувати як булінг. 3 цього часу судові органи почали активну роботу над відповідними справами та виносити рішення щодо них. Актуальність дослідження проблематики булінгу у правовій науці зумовлена наявністю справ, пов’язаних з булінгом. Аналіз цих справ дасть можливість надалі сформувати конкретні пропозиції, спрямовані на мінімізацію такого явища, як булінг, надати пропозиції щодо підвищення ефективності заходів протидії.

Аналіз останніх досліджень і публікацій. Серед фахівців, які досліджували булінг, можна виділити таких як: С. Поляруш, Н. Прібиткова, А. Губко, О. Кормило, А. Король, Л. Лушпай, Т. Алєксєєнко, О. Барліт, В. Олійник та інші, їхні роботи мають загальнотеоретичний характер. Проблеми насильства у навчальних закладах та запобігання йому в українській адміністративно-правовій науці досліджували С. Черноп'ятов, О. Іваній, Ю. Левченко, Б. Логвиненко, О. Мельничук, Т. Лежнєва, Р. Опацький, Н. Опольська та інші.

Мета статті полягає в аналізі теоретичного та практичного погляду на явище булінг (цькування), дослідження судових справ, пов'язаних з булінгом в освітньому середовищі.

Виклад основного матеріалу дослідження. Про булінг як проблему відомо ще з XVI століття. Булінг (bullying, від анг. bully - хуліган, забіяка) (цькування) -цедіяння (діїабобездіяльність)учасників освітньогопроцесу, якіполягають 
у психологічному, фізичному, економічному, сексуальному насильстві, у тому числі із застосуванням засобів електронних комунікацій, що вчиняються стосовно малолітньої чи неповнолітньої особи та (або) такою особою стосовно інших учасників освітнього процесу, внаслідок чого могла бути чи була заподіяна шкода психічному або фізичному здоров'ю потерпілого.

Одним із перших почав вивчати проблему булінгу скандинавський учений Девід Олвеус, ще у 70-х рр. досліджуючи це явище серед хлопчиків. Він розумів булінг як умисну, систематично повторювану та агресивну поведінку, що включає нерівність соціальної влади або фізичної сили [1]. Д. Ольвеус та його колега Н. Голованова розглядають такі форми цькування, як: вербальне, сексуальне, фізичне насильство, знущання за допомогою брехні або брехливих чуток про жертву; агресії: відбирання грошей або інших речей, їх псування; загрози або примушення виконувати будь-які дії; расистський булінг; сексуальний булінг і ін. Вирізняють ще різні ступені насильства, кожен з яких може завдавати шкоди психічному чи фізичному здоров'ю, соціальному становищу, матеріальним та нематеріальним інтересам або порушити права жертви. Н. Голованова зазначає, що булінг видозмінюється, з технічним прогресом набуває нових форм, але залишає свою основну суть - домінування та приниження людини. У середовищі неповнолітніх булінг виявляється через різні акти фізичного або психологічного насильства та утисків, пережитих дітьми, з боку інших дітей. Це можуть бути: систематичні глузування, що відображають якісь особливості зовнішнього вигляду або особистості потерпілих; псування їхніх особистих речей, заштовхування під парту, вимагання грошей; відверті знущання, що принижують почуття людської гідності.

3 точки зору Л. Кішлі існують такі ознаки булінгу: емоційне приниження, що включає вербальні і невербальні способи вираження; продовження емоційно образливої і принизливої поведінки впродовж тривалого періоду; непривітна і недовірлива поведінка; втручання в приватне життя людини; погіршення психологічного і фізичного стану людини, на яку спрямована агресія; намір завдати шкоду іншій людині, що дозволяє чи сприяє, щоб ця людина пережила травмуючі події; агресор займає вище становище, ніж його жертва, i, відповідно, дозволяє собі дії, що принижують гідність і завдають моральної або фізичної шкоди іншій людині [6].

На думку А. Король, усі дії, які утворюють булінг, попри їх різноманіття, мають спільні риси: 1) дисбаланс влади, тобто кривдник та жертва обов'язково різні за соціальним статусом, фізичною чи психологічною адаптованістю до середовища, різної статі, раси, релігії, сексуальної орієнтації тощо; 2) намір нашкодити, тобто кривдник навмисно викликає емоційний або фізичний біль у потерпілого, насолоджується спостерігаючи; 3) погроза подальшої агресії, тобто кривдник i жертва розуміють, що це не перший і не останній випадок знущання.

Ці риси частково враховані і в Законі України «Про освіту», де зазначено такі типові ознаки булінгу (цькування), як: систематичність (повторюваність) діяння; наявність сторін - кривдник (булер), потерпілий (жертва булінгу), спостерігачі (за наявності); дії або бездіяльність кривдника, наслідком яких є заподіяння психічної та/або фізичної шкоди, приниження, страх, тривога, підпорядкування потерпілого інтересам кривдника, та/або спричинення соціальної ізоляції потерпілого [3]. 
Соціальну природу булінгу можна розглядати крізь призму причин цього явища, більшість яких має соціальний характер: наявність у суспільстві фактично неконтрольованої пропаганди насильства та жорстокості; відсутність реальних дій, спрямованих на підвищення матеріального добробуту сімей; незадовільний стан роботи з підвищення рівня правової культури громадян; відсутність всебічної пропаганди ідей ненасильницького співіснування тощо.

Говорячи про світовий досвід із розв'язання цього питання, варто відзначити, що однією з перших країн, де про проблему булінгу почали говорити на національному та законодавчому рівнях, стала Швеція. Тут, окрім законів, що захищають жертв цькування, впроваджено закріплену в законодавстві системну профілактичну роботу, яку здійснюють державні установи та некомерційні організації, на кшталт “Friends". Найефективнішою антибулінговою програмою визнано норвезьку загальнонаціональну програму Д. Ольвеуса, результати багатолітнього моніторингу якої продемонстрували свою дієвість - вона на 30-50\% знижує кількість інцидентів, пов'язаних з цькуванням. Одночасно знижуються й показники антисоціальної поведінки, включаючи пияцтво, крадіжки, вандалізм тощо, а також покращується загальний клімат у школах. Така програма засновується на принципах, що передбачають створення теплого та позитивного шкільного (в ідеалі - і домашнього) середовища, та ставить акцент не на покаранні, а на заохоченні до мирного співіснування з твердими рамками й обмеженнями неприйнятної поведінки.

Поруч зі Швецію і Канада офіційно визнала проблему булінгу і почала розробку відповідного законодавства (Хартія безпечних шкіл) щодо протидії цьому негативному явищу. 30.11.2011 р. Уряд провінції Онтаріо прийняв Закон «Про навчальні заклади» (“The Accepting Schools Act”), щоб створити «режим» обізнаності про знущання в школах, організувати навчання з питань запобігання та протидії булінгу. Здобули поширення в друкованих виданнях та засобах масової інформації матеріали про самогубства канадських учнів Джеймі Хаблі з Оттави і Мітчелла Уїлсона з Пікерінга, які стали каталізатором до прийняття нового законодавства.

Виявивши ситуацію не лише відкритого цькування однолітків, а й збройних нападів і вбивств у освітніх закладах, американські законодавці рушили шляхом видання в окремих штатах спеціальних законів про боротьбу з булінгом та агресією в школі. У результаті на сьогодні всі штати США мають відповідні правові акти. Джорджія стала першим штатом, який прийняв такий закон ще в 1999 році (1999 Georgia Laws, HB 84, Chap. 282 (OCGA § 20-2-751.4 and OCGA § 20-2-751.5)) [23], а Монтана - останнім, який відповідний закон прийняв у квітні 2015 року (Bully-Free Montana Act - НB 0284). До речі, останній правовий акт лише визначає поняття «знущання (цькування)», але не містить розгорнутих вимог щодо шкільної політики у напрямі запобігання булінгу.

У США 2018 року стартувала спеціалізована платформа "stopbullying.gov", що деталізує всі види булінгу, які зараз набувають поширення (залежно від релігії, раси, сексуальної орієнтації, обмежених фізичних можливостей, кібербулінг тощо), і методи протидії їм. Уряд США переконаний, якщо булінг має дискримінаційну спрямованість, пов'язану з расою, національністю, статтю, релігією жертви, 
навчальні заклади, які фінансуються з федерального бюджету, зобов'язані розглядати питання про залякування (harassment) як порушення цивільних прав особи.

Ч. 1 ст. 16 Конвенції про права дитини передбачає, що жодна дитина не може бути об'єктом свавільного або незаконного втручання у здійснення її права на особисте та сімейне життя, недоторканність житла, таємницю кореспонденції або незаконного посягання на її честь і гідність. Згідно зі ст. 52 Конституції України, діти рівні у своїх правах незалежно від походження, а також від того, народжені вони у шлюбі чи поза шлюбом. Будь-яке насильство над дитиною та їі експлуатація переслідуються за законом.

В Україні на державному рівні визнали проблему булінгу (цькування) шляхом прийняття Закону України «Про внесення змін до деяких законодавчих актів України щодо протидії булінгу (цькуванню)». Незважаючи на те, що ця проблема не нова, такої ідеї в нашому правовому полі не було до 2019 року. Цей Закон визнав той факт, що проблема полягає не лише у соціально-педагогічному, психологічному явищі, а й у тому, що булінг є формою насильства. Відповідно до цього закону поняттям «булінг» доповнено пункт 3 статті 1 Закону України «Про освіту» . Крім вищезазначених типових ознак булінгу, законодавчо закріплена наявність сторін - кривдник (булер), потерпілий (жертва булінгу), спостерігачі (за наявності); дії або бездіяльність кривдника, наслідком яких є заподіяння психічної або фізичної шкоди, приниження, страх, тривога, підпорядкування потерпілого інтересам кривдника або соціальна ізоляція потерпілого.

Кодекс України про адміністративні правопорушення було доповнено ст. 173-4, де визначено, що булінг (цькування) як діяння учасників освітнього процесу, які полягають у психологічному, фізичному, економічному, сексуальному насильстві, у тому числі із застосуванням засобів електронних комунікацій, що вчиняються стосовно малолітньої чи неповнолітньої особи або такою особою стосовно інших учасників освітнього процесу, внаслідок чого могла бути чи була заподіяна шкода психічному або фізичному здоров'ю потерпілого [8].

Як адміністративний проступок булінг проявляється у діях чи бездіяльності кривдника, наслідком яких є заподіяння психологічної або фізичної шкоди, приниження, страх, тривога, підкорення потерпілого інтересам кривдника або соціальна ізоляція потерпілого. За вчинення такого адміністративного проступку передбачено притягнення до адміністративної відповідальності у вигляді накладення штрафу від п'ятдесяти до двохсот неоподатковуваних мінімумів доходів громадян або громадські роботи на строк від двадцяти до шістдесяти годин, залежно від тяжкості вчинення проступку [8].

Підстави притягнення до відповідальності за булінг: протиправність, винність, адміністративна караність та суспільна небезпечність. Протиправність виявляється у забороні вчинення дій учасників освітнього процесу, які передбачені статтею 173-4 КУпАП, а саме фізичного, економічного, психологічного, сексуального насильства. Винність у діях чи бездіяльності полягає у вчиненні булінгу навмисно чи з необережності. Наслідком булінгу є адміністративна караність, яка виявлена у застосуванні до винної особи стягнення у вигляді накладення штрафу від п'ятдесяти до двохсот неоподатковуваних мінімумів доходів громадян 
або громадські роботи на строк від двадцяти до шістдесяти годин, залежно від тяжкості вчинення проступку.

Через те, що Кримінальним кодексом України все ще не передбачена відповідальність за вчинення булінгу, у випадках, коли він має фізичний характер і завдає шкоди здоров'ю людини, тобто виходить за межі визначення адміністративного проступку і має ознаки злочину, до кривдника застосовуються стаття 120 «Доведення до самогубства», стаття 121 «Умисне тяжке тілесне ушкодження», стаття 122 «Умисне середньої тяжкості тілесне ушкодження», стаття 125 «Умисне легке тілесне ушкодження».

За статистичними даними Національної поліції України, упродовж 2020 року за фактами булінгу (ст. 173-4 КУпАП - Булінг (цькування) учасника освітнього процесу) працівниками поліції складено 253 протоколи про адміністративне правопорушення. На профілактичний облік за фактами вчинення булінгу поставлено 25 осіб (дані станом на 12.03.2021). За даними Єдиного державного реєстру судових рішень, станом на 13.05.2021 р. суди розглянули більше ніж 900 справ про булінг, винесені відповідні ухвали та постанови.

Формами судових рішень виступає: ухвала суду - письмове або усне судове рішення, яким вирішуються питання, що пов'язані з процедурами розгляду справ, та постанова - письмове судове рішення, в якому справа вирішується по суті. Вони виступають безпосереднім предметом нашого дослідження.

Так, Постанова Жовтневого районного суду м. Харкова від 15.04.2020 (справа № 639/1214/20) визначає таку фабулу справи, яка випливає із протоколу про адміністративне правопорушення серії АПР18 471171 від 20.02.2020 р. Зокрема, вчитель математики з травня 2018 року по 25.12 .2019 року в приміщенні школи під час уроків математики систематично вчиняв психологічне насилля стосовно учня 7-2 класу, у зв'язку з чим батьком дитини останню було переведено до іншого навчального закладу. Своїми діями вчитель порушив вимоги ч. 1 ст. 173-4 КУпАП.

У судовому засіданні батько потерпілого повідомив, що з травня 2018 року стосовно його сина вчиняються дії, що мають ознаки «Булінгу». Дії мають тривалий характер та нанесли шкоду психічному здоров'ю його сина. В травні 2018 року він став свідком неконтрольованої агресії з боку вчителя математики, яка супроводжувалась принизливими висловлюваннями стосовно його сина, зробивши при цьому зауваження, що йому слід бути більш стриманим у своїх емоціях. Однак замість вибачень це викликало низку неадекватних дій з боку вчителя. 3 цього моменту починається повільне і методичне отруєння життя дитини, яке тривало протягом 2019-2020 навчального року.

У зв'язку з вищевикладеним батько просив притягнути вчителя до адміністративної відповідальності та визнати винним за ч. 1 ст. 173-4 КУпАП.

Винуватість учителя у діях, передбачених ч. 1 ст. 173-4 Кодексу України про адміністративні правопорушення, підтверджується дослідженими у судовому засіданні доказами, зокрема: довідкою про результати розгляду матеріалу ЖЖЕО № 23266 від 26.12.2019 року за заявою; заявою від 25.11.2019 року, яка адресована директору закладу; аудіозаписом з уроків за участю порушника; розшифровкою файлу аудіозапису; письмовими поясненнями потерпілого; письмовими поясненнями свідків. 
Суд дійшов висновку, що обвинувачений справді вчинив діяння, передбачені ч. 1 ст. 173-4 КУпАП, що тягне за собою накладення адміністративного стягнення, яке виразилося в діянні учасників освітнього процесу, які полягали у психологічному насильстві стосовно неповнолітньої особи, внаслідок чого була заподіяна шкода психічному здоров'ю потерпілого.

Згідно із зазначеним вище протоколом про адміністративне правопорушення, правопорушення, яке інкриміноване вчителю, вчинене останнім у період з травня 2018 року по 25.12.2019 року, тобто на час розгляду адміністративного матеріалу судом (15.04.2020 року) строки притягнення до адміністративної відповідальності вже сплинули.

Відповідно до п. 7 ст. 247 Кодексу України про адміністративні правопорушення провадження у справі про адміністративне правопорушення не може бути розпочато, а розпочате підлягає закриттю в разі закінчення на момент розгляду справи строків, передбачених КУпАП. Згідно з ч. 2 КУпАП, якщо справи про адміністративні правопорушення підвідомчі суду (судді), стягнення може бути накладено не пізніш як через три місяці з дня вчинення правопорушення.

Закриття провадження у справі про адміністративне правопорушення з підстав закінчення строків, передбачених ст. 38 КУпАП, можливе лише за умови встановлення факту вчинення особою протиправної дії чи бездіяльності, що підпадають під визначені законом ознаки адміністративного правопорушення.

Керуючись ст. 38, 173-4 ч. 1, 247 п. 7, 283-285 Кодексу України про адміністративні правопорушення, суд постановив: визнати винуватим учителя у вчиненні правопорушення, передбаченого ч. 1 ст. 173-4 КУпАП. Провадження у справі про адміністративне правопорушення закрити у зв'язку із закінченням строків накладення адміністративного стягнення. Сплив строку давності можна вважати проблемою, з якою стикаються у великій кількості судових справ, пов’язаних 3 діями, які кваліфікуються як булінг, вирішенням якої можуть стати відповідні зміни в чинному законодавстві, яке регулює це питання.

Звернемося до наступного судового рішення. Так, постанова Краматорського суду Донецької області 19.02 .2019 р. (справа № 234/2837/19) визначає, що, згідно з протоколом про адміністративне правопорушення від 06.02.2019 р. серії ГП № 232422, особа ухилялась від виконання передбачених ст. 150 СК України обов'язків щодо виховання доньки, внаслідок чого остання 31.01.2019 року вчинила дії, передбачені ст. 173-4 КУпАП. Таким чином, особа вчинила адміністративне правопорушення, передбачене ч. 13 ст. 184 КУпАП.

Ця справа є яскравим прикладом неправильної кваліфікації вчинюваних дій. Так, як і у наведеному прикладі, досить часто поліцейські кваліфікують дії за ч. 3 ст. 184 КУПАП (невиконання батьками або особами, що їх замінюють, обов'язків щодо виховання дітей), хоча правильною кваліфікацією є ч. 3 або 4 ст. 173-4 КУПАП (булінг (цькування) учасника освітнього процесу). Деякі суди також неправильно кваліфікують дії батьків, діти яких вчинили булінг.

У разі вчинення булінгу малолітніми або неповнолітніми особами віком від чотирнадцяти до шістнадцяти років необхідно кваліфікувати дії за спеціальною нормою статті 173-4 КУпАП [8], а не загальною, передбаченою 
статтею 184 КУпАП [8], про що прямо вказано в Законі. Зокрема, спеціальним суб'єктом у частинах 3 та 4 статті 173-4 КУпАП є батьки або особи, які їх замінюють, чиї малолітні або неповнолітні діти віком від чотирнадцяти до шістнадцяти років вчинили булінг.

Досить нетиповою є судова справа про вчинення булінгу малолітньою особою не лише щодо інших дітей, а й щодо вчителя. Наприклад, постанова Нікопольського міськрайонного суду Дніпропетровської області 15.06.2021 р. (справа №182/2610/21) за протоколом про адміністративне правопорушення серії ВАБ № 490153 від 19 квітня 2021 року. Малолітній учень протягом 2020 та 2021 навчального року на території школи вчинив булінг (цькування) стосовно малолітніх однокласників та вчителів навчального закладу, яке виразилось у психологічному та фізичному насильстві, а саме систематичних образах, штовханні, нецензурних висловлюваннях та жестах, внаслідок чого могло бути завдано шкоду психічному та фізичному здоров’ю потерпілих. За цих обставин адміністративну відповідальність за скоєне малолітнім учнем несе його мати [11].

Протокол про адміністративне правопорушення за такою справою не може бути визнаний належним доказом у цій справі в розумінні статті 251 КУпАП, оскільки в ньому не зазначено, які саме насильницькі дії були вчинені малолітнім стосовно потерпілих. Також у ньому вказано, що потерпілим (малолітнім однокласникам та вчителям навчального закладу) могла бути заподіяна шкода психічному або фізичному здоров'ю, але зовсім не конкретизовано потерпілих у справі. Крім того, протокол не містить час/дату виявлення інкримінованого діяння, а лише вказано період вчинення правопорушення, справа надійшла до суду пізніше, тобто до закінчення вказаного в протоколі періоду.

Як бачимо, саме через відсутність фактів вчинення малолітнім учнем булінгу (цькування) притягнення його матері до адміністративної відповідальності за таке правопорушення виключається.

Підсумовуючи, необхідно вказати на те, що існує проблема неправильного складання протоколів щодо булінгу. Її можна легко подолати, якщо більш уважно та професійно здійснювати провадження у справах про адміністративне правопорушення, передбачене статтею 173-4 КУпАП.

Схожа фабула справи визначена і постановою Жовтоводського міського суду Дніпропетровської області 12.07.2021 р. (справа № 176/1146/21), відповідно до протоколу про адміністративне правопорушення від 06.05.2021 серії ВАБ № 489088, що складений стосовно учня 1 за ч. 3 ст. 173-4 КУпАП, згідно з яким 14.04.2021 року в період з 12:00 по 12:50 під час освітнього процесу, а саме онлайнуроку на платформі “Google classroom”, учень 7-го класу КЗ3СО № 12 систематично вчиняв психологічне насильство стосовно вчителя української мови, що виразилось в ображанні її нецензурною лайкою, внаслідок чого була завдана шкода психологічному і фізичному здоров'ю [12].

У судовому засіданні звинувачений свою вину у вчиненні адміністративного правопорушення, передбаченого ч. 3 ст. 173-4 КУпАП, не визнав, суду пояснив, що його підопічний онук запевняє його, що вищезазначеного він не вчиняв, а це зробив хтось інший із однокласників, хто саме він не знає. 
Вчитель суду пояснила, що 14 квітня 2021 року вона проводила онлайн-урок із учнями 7-го класу на відповідній платформі. Під час уроку, коли вона увімкнула презентацію, вона почула фразу «я мусульманин», хто саме її промовив вона не знає. Потім на екрані почали з'являтися картинки з написами у нецензурній формі і все це супроводжувалося піснями з нецензурною лексикою. Про те, що урок їй зірвав саме цей учень, їй стало відомо від батьків інших учнів класу, які були присутні під час уроку разом з дітьми. Однозначно сказати, що цю подію організував саме він, вона не може. Відеозапис онлайн-уроку, на жаль, не зберігся.

Варто зазначити, що не кожен конфлікт є булінгом. Цькування - це тривалі, повторювані дії, а одинична конфліктна ситуація між учасниками таким не може вважатися.

Так, у протоколі про адміністративне правопорушення суть адміністративного правопорушення викладена у загальному порядку, без конкретизації об'єктивних ознак складу адміністративного правопорушення, передбаченого ч. 3 ст. 173-4 КУпАП. Зокрема, не зазначено, чи мало діяння систематичний характер, якщо так, то в який період часу, з конкретною вказівкою на час кожної події, які наслідки викликали насильницькі дії у потерпілого та чи були вони взагалі.

Матеріали справи про адміністративне правопорушення також не містять доказів, які б переконливо вказували на вчинення малолітнім дій, зазначених у протоколі про адміністративне правопорушення та диспозицією ч. 3 ст. 173-4 КУпАП. Справу закрито через відсутність складу правопорушення.

Ще одним цікавим прикладом можна розглянути Постанову Бучацького районного суду Тернопільської області 26.11.2019 р. (справа № 595/2070/19), згідно з якою 26.09.2019 р. завідувач Малозаліщицької ЗОШ І ст. не вжила заходів щодо припинення булінгу щодо малолітньої учениці 2-го класу та не повідомила уповноважені підрозділи Національної поліції України про факт булінгу в навчальному закладі, в якому вона є керівником, чим вчинила адміністративне правопорушення, передбачене ч. 5 ст. 173-4 КУпАП. Завідувач у судовому засіданні вину заперечила, пояснивши суду це тим, що їй було не відомо про факти булінгу [13].

Відповідно до зазначених обставин вина завідувача у скоєнні правопорушення підтвердилася даними, що містяться в протоколі про адміністративне правопорушення серії АПР18 № 097480 від 18.10.2019 р., та письмовими поясненнями свідків. Слід сказати, що вина завідувача підтверджується письмовими поясненнями потерпілої дитини, з яких вбачається, що щодо їі онуки систематично вчинявся булінг, про що вона повідомляла класного керівника та завідувача школи, однак заходів для його припинення вжито не було. У зв'язку з цим вона була змушена перевести дитину до іншої школи.

Твердження завідувачки про те, що їй не було відомо про випадок булінгу, суд оцінив критично, оскільки спростовується показами свідка та іншими матеріалами справи.

За цих обставин суд вважає, що в діях завідувача містяться ознаки адміністративного правопорушення, передбаченого ч. 5 ст. 173-4 КУпАП, а саме неповідомлення керівником закладу освіти уповноважених підрозділів органів Національної поліції України про випадки булінгу (цькування) учасника освітнього процесу. 
Суд постановив визнати винною завідувача Малозаліщицької ЗОШ I ст. у скоєнні правопорушення, передбаченого ч. 5 ст.173-4 КУпАП, та накласти на неї адміністративне стягнення у вигляді штрафу в розмірі 75 неоподатковуваних мінімумів доходів громадян, що становить 1275 (одну тисячу двісті сімдесят п’ять) грн. Ця судова справа дає змогу зазначити, що судові органи досить категорично та критично налаштовані щодо відповідальних за освітній процес.

Висновки. Нині Україна, як і багато інших держав світу, перебуває на початковому етапі становлення антибулінгової стратегії. Держава вже почала вдаватися до реформ шляхом прийняття низки відповідних законодавчих новел стосовно булінгу. Це зумовлено активним розвитком цього негативного явища, збільшення небезпеки, негативних наслідків його впливу для психологічного, соціального розвитку дітей та підлітків. У результаті тривалого насилля дитина може отримати глибоку психологічну травму, яка в майбутньому перешкоджатиме нормальному розвитку особистості. Не отримуючи підтримки у ситуаціях насильства, діти, що постраждалі, можуть завдати собі шкоди, зокрема, доводячи себе до самогубства.

Провівши аналіз судових справ, пов'язаних із вчиненням булінгу, можна зробити певні висновки. Так, нині спостерігається відсутність одного критерію для вирішення справ, в яких склад адміністративного правопорушення є однаковим або дуже подібним. На нашу думку, це зумовлено тим, що юридична відповідальність за вчинення булінгу - нові епізоди у сучасній юриспруденції. Це визначає складність винесення уніфікованих постанов. Нині відсутнє чітке розуміння сутності булінгу, його характерних ознак. Через це на практиці досить складно ідентифікувати булінг як під час судового розгляду, так і на стадії складання протоколу про адміністративне правопорушення.

Явище булінгу ще не знайшло достатньої об'єктивізації в кримінально-правовій науці. На наш погляд, для правильного регулювання випадків булінгу, в яких простежується перехід до агресивних дій (завдання шкоди здоров'ю людини), що носять злочинний характер, слід говорити про наявну криміногенну ситуацію, за якої діяння кваліфікується як злочин, доречно буде запровадити кримінально-правову відповідальність, позаяк такі дії виходять за межі визначення адміністративного проступку, і має ознаки злочину.

Ми вважаємо, що необхідне створення нового дієвого правового механізму протидії явищу булінгу, яке вимагає врахування зарубіжного досвіду, адже досліджувана проблема не має кордонів і постає навіть перед соціально благополучними країнами.

Отже, для науки права явище булінгу було й досі залишається одним з інноваційних та потребує грунтовних досліджень як з теоретичного, так і з практичного погляду, доповнення та оновлення чинного законодавства відповідно до нововиявлених фактів.

\section{Jimepamypa}

1. Аверьянов А. И. Школьный буллинг в воспоминаниях студентов МГПИ. Современные проблемы и пути их решения в науке, транспорте, производстве и образовании : материалы междунар. научн.-практ. конф. Вып. 4. Т. 15. Одесса, 2011.

2. Лушпай Л. І. Шкільний булінг як різновид суспільної агресії. Наукові записки Нац. ун-ту «Острозька академія». Серія: Філологічна. 2013. Вип. 33. С. 85. URL: http://nbuv.gov.ua/ j-pdf/ Nznuoaf_2013_33_28.pdf 
3. Про внесення змін до деяких законодавчих актів України щодо протидії булінгу (цькуванню) : Закон України від 18.12.2018 № 2657-VIII. Відомості Верховної Ради. 2019 № 5, ст. 33.

4. Олійник В. О. Характеристика сучасних форм та видів жорстокої поведінки учнів основної школи. Sciences of Europe. 2017. № 11(11). С. 37-41.

5. Падучак О. Булінг - стоп! Аналіз першого року реалізації Закону щодо протидії булінгу. Юридична газета online. 2020. № 1(707). URL: https://yur-gazeta.com/publications/practice/inshe/buling-stop-analiz-pershogo-roku-realizaciyi-zakonu -shchodo-protidiyi-bulingu.html

6. Randall P. Bullying in Adulthood: Assessing the Bullies and Their Victims. Florence, KY, USA : Brunner-Routledge, 2001. URL: http:/site.ebrary.com/lib/bckharkiv/Doc?id=10053591

7. UNICEF in Ukraine. URL: https://www.unicef.org/ukraine

8. Кодекс України про адміністративні правопорушення від 07.12.1984 року № 8073-X. URL: https://zakon.rada.gov.ua/laws/show/ 80731-10

9. Постанова Жовтневого районного суду м. Харкова від 15.04.2020 р. Справа № 639/1214/20. URL: https://reyestr.court.gov.ua

10. Постанова Краматорського суду Донецької області 19.02.2019 р. Справа № 234/2837/19. URL: https://reyestr.court.gov.ua

11. Постанова Нікопольського міськрайонного суду Дніпропетровської області 15.06.2021 p. Справа № 182/2610/21. URL: https://reyestr.court.gov.ua

12. Постанова Жовтневого суду Миколаївської області 06.03.2020 р. Справа № 477/49/20. URL: https://reyestr.court.gov.ua

13. Постанова Бучацького районного суду Тернопільської області 26.11.2019 р. Справа № 595/2070/19 URL: https://reyestr.court.gov.ua

\section{Анотація}

Соколова I. О., Філіппова А. Ю. Аналіз судової практики щодо булінгу в освітніх закладах України. - Стаття.

У статті проаналізовано п’ять судових справ щодо вчинення булінгу (цькування) в освітньому середовищі в Україні. Підкреслюється, що така серйозна проблема, як булінг, у всьому світі існує досить давно. Україна, як і більшість зарубіжних країн, перебуває на початковому етапі становлення антибулінгової протидії.

Визначено поняття та основні ознаки, риси та соціальну природу булінгу, його характеристику 3 точки зору чинного законодавства та наукових досліджень вітчизняних та зарубіжних науковців. Проаналізована практика деяких країн світу щодо протидії явищу булінгу.

Наголошується, що натепер в Україні спостерігається відсутність одного критерію для вирішення справ, в яких склад адміністративного правопорушення є однаковим або дуже подібним. Складність винесення уніфікованих постанов зумовлена тим, що явище булінгу для сучасної юриспруденції є досить новим.

3'ясовано, що нині відсутнє чітке розуміння сутності булінгу, його характерних ознак. Через це на практиці досить складно ідентифікувати булінг як під час складання протоколу про адміністративне правопорушення, так і судового розгляду.

Встановлено, що в кримінально-правовій науці явище булінгу не має об'єктивізації. Дії, у яких простежується перехід до агресивних дій (завдання шкоди здоров'ю людини), виходять за межі визначення адміністративного проступку і мають ознаки злочину. У такому разі має місце запровадження окремої кримінально-правової відповідальності за вчинені дії.

Зауважується, що необхідне створення дієвого правового механізму протидії явищу булінгу, яке має грунтуватися на досвіді інших країн світу, адже досліджувана нами проблема не має кордонів.

Ключові слова: булінг, освітній процес, судові рішення, постанови, адміністративна відповідальність, адміністративний проступок.

\section{Summary}

Sokolova I. O., Filippova A. Yu. Analysis of judicial practice on bullying in educational institutions of Ukraine. - Article.

The article analyzes five court cases related to bullying (harassment) in the educational environment in Ukraine. It is emphasized that the problem is as serious as bullying, it has existed all over the world for a long time. Ukraine, like most foreign countries, is at the beginning of the formation of anti-bullying counteraction. 
The concept and main features, features and social nature of bullying, its characteristics in terms of current legislation and research of domestic and foreign scientists are defined. The practice of some countries of the world to counteract the phenomenon of bullying is analyzed.

It is emphasized that today in Ukraine there is no single criterion for resolving cases in which the composition of an administrative offense is the same or very similar. The difficulty of issuing unified regulations is due to the fact that the phenomenon of bullying for modern jurisprudence is quite new.

It was found that there is currently no clear understanding of the essence of bullying, its characteristics. Because of this in practice it is quite difficult to identify bullying as when drawing up a report on an administrative offense and a trial.

It has been established that the phenomenon of bullying has no objectification in criminal law science. Actions that trace the transition to aggressive actions (harm to human health) go beyond the definition of an administrative offense and have the characteristics of a crime. In this case, there is an introduction of a separate criminal liability for the acts committed.

It is noted that it is necessary to create an effective legal mechanism to combat the phenomenon of bullying, which should be based on the experience of other countries, because the problem we are studying has no borders.

Key words: bullying, educational process, court decisions, resolutions, administrative responsibility, administrative misconduct. 